\title{
The Path of Phocion: Disgrace and Disavowal at the Philip Johnson Glass House
}

Philip Johnson graced his iconic Glass House with a single seicento painting, Landscape with the Burial of Phocion by Nicolas Poussin, an intrinsic signifier of the building that frames it. Analyzed within its physical, cultural, and political context, Burial of Phocion condenses displaced, interlacing representations of disavowed aspects of Johnson's identity, including forbidden strivings for greatness and power, the haunting legacy of the lesser artist, and the humiliation of exile. It is argued that Phocion's path from disgrace to posthumous dignity is a narrative lens through which Johnson attempted to reframe and disavow his political past.

Every time I come away from Poussin I know better who I am.

—attributed to Paul Cézanne

Is all that we see or seem

But a dream within a dream?

-Edgar Allan Poe, a Dream Within a Dream, $1827^{1}$

\section{An Invitation to Look}

Although he would during his life amass a formidable collection of contemporary art, the architect Philip Cortelyou Johnson (1906-2005) chose to grace his country residence, the Glass House, with but a single seicento Old Master painting, Nicolas Poussin's Landscape with the Burial of Phocion, ${ }^{2}$ which was

This study was undertaken with the gracious cooperation of the Philip Johnson Glass House of the National Trust for Historic Preservation. Special thanks go to Dorothy Dunn of The National Trust. The author also wishes to thank Hillary Beattie, Steve Brosnahan, David Carrier, Daria Colombo, Wendy Katz, Eric Marcus, Jamie Romm, and Jennifer Stuart, and gratefully acknowledges the generosity of the late Richard Kuhns. 
purchased and installed in the Glass House soon after it was completed in 1949 (Fig. 1). After experimenting with other paintings, Johnson placed the Poussin on an upright easel in the same privileged position it occupies today, sixty years later, adjacent to the hearth at the center of the house and prominently visible from the sitting area.

The famed Glass House is an important Modernist monument, stewarded since Johnson's death by The National Trust for Historic Preservation (Dunn \& Maclear, 2008). The Glass House proper is only one of a group of eight buildings Johnson built on his forty-nine acre estate in New Canaan, Connecticut. Long established as a respected critic and curator of architecture and design, Johnson made his highly visible debut as an architect with the Glass House, a critical success that presaged a long and productive career. But if Johnson's design legacy is not without its disputes, it is his political history as a protoFascist and Nazi sympathizer in the years leading to World War II that continues to provoke the most controversy-a history he attempted to put behind him after reinventing himself as an architect, collector, and patron of the arts. In this effort, I will attempt to show that condensed, displaced representations of crucial aspects of its architect's identity converge within the intrinsic signifier of the Glass House, Burial of Phocion. In particular, I shall argue that this work of art crystallizes conflicts around power, greatness, and dynastic succession, along with shameful narratives of disgrace and exile. Further, the idealized aesthetic symbolization of these conflicts acts to disavow and reframe their manifestations, including Johnson's catastrophic proto-Fascist political strivings.

As a work of art embedded within an encompassing work of art and as a work integral to Johnson's strategy of reframing, Burial of Phocion can be understood as analogous to a "dreamwithin-a-dream," as Grinstein (1956) and Balter (2006) would argue. Accordingly, this essay will approach the Glass House as a "dream" construct, whose manifest design contains latent representations of its architect, alongside more consciously purposeful ones. The significance of this approach derives in important part from Freud's conjecture that dreams-withindreams-and, by hypothetical extension, works of art-within- 


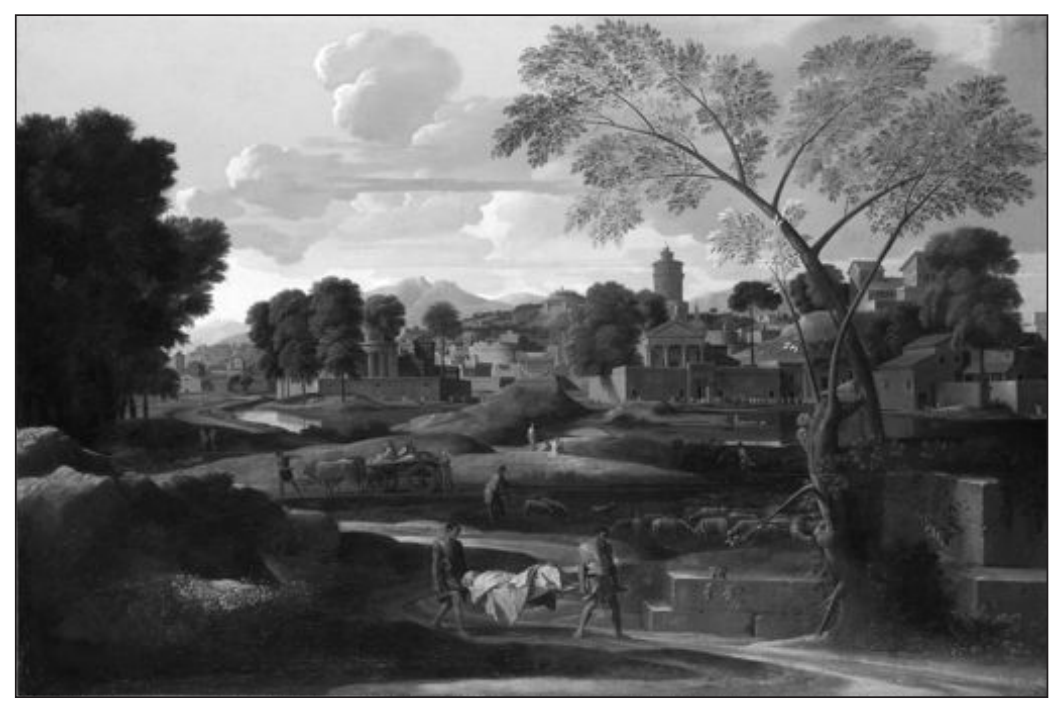

Figure 1. Landscape with the Burial of Phocion, N. Poussin, 1648, Hotel Matignon, Paris. One of three known copies, the Paris canvas, otherwise identical to the copy in New Canaan, is shown for illustrative purposes here because of its superior preservation. Image (C) Réunion des Musées Nationaux/Art Resource, New York. Used with permission.

works of art-contain realities that need to be mitigated, repudiated, or kept out of conscious awareness altogether, as if in effect the dream was attempting to say "after all this is only a dream:"”

what has been "dreamt" in the dream is a representation of the reality, the true recollection, while the continuation of the dream, on the contrary, merely represents what the dreamer wishes. To include something in a "dream within a dream" is thus equivalent to wishing that the thing described as a dream had never happened ... [T] his implies the most decided confirmation of the reality of the event . . . The dream-work makes use of dreaming as a form of repudiation ... (Freud, 1900, p. 338).

Similarly, Balter (2005; 2006) emphasizes that works of artwithin-works of art tend to contain intolerable realities requiring the greater measure of negation, distortion, or denial provided by this extra layer of aesthetic representation. Indeed, although 
"Residence in New Canaan," the unconventional essay in which he unveiled the Glass House in 1950, is literally saturated with a litany of art-historical attributions, Johnson-in stark contrast to his otherwise constitutive erudition-was silent regarding the installation of Burial of Phocion, consistent with the desire to neglect whichever aspects of himself were in fact embedded within it. Disguised perhaps in a painting-but in plain view. Like dreams, which promise a wealth of encrypted meanings, houses of glass, "simultaneously revealing and concealing, convince the viewer that everything can be told inside while nothing will be told outside" (Lavin, 2004, p. 67). Certainly, a house of glass invites us to look inside. And when we do, we see the Poussin.

\section{A Minor Punctuation of Space}

It comes as a surprise to the psychoanalyst visiting the Glass House that for all the critical interest it has attracted, scant attention has been paid to the single painting displayed in it. And for all Johnson's curatorial importance within the world of contemporary art, little is known about the rationale behind this evidently highly deliberate and enduring design choice. This is perhaps not surprising, given the emphasis in post-modern discourse on form and structure rather than content. Accordingly, Kipnis (1993) sees Burial of Phocion as a demarcation of interior space, and as serving a secondary, generic function as a work of art:

... the Poussin painting serves as a work of art, as a wall delimiting the room within which the living room sits, as a door to the bedroom, as an object floating in the intermediate register of the section ... and as an edge of the modeled residual space... (p. xvii).

Despite his prescient appreciation of the painting's "precise and meticulous overdetermination" (xvii), Kipnis is concerned with its placement and form, not its subject. An earlier commentator, Arthur Drexler (1949), is more attentive to the painting itself, and to its painter. 
A Poussin painting on a metal easel, near the cluster of chairs, is set just where the conventional might have placed an abstraction. By a fortunate arrangement between the architect and the landscape, the trees outside now resemble those in the painting .... At the other end of the room a statue by Elie Nadelman serves as a minor punctuation of space, much the way the free standing Poussin landscape does (pp. 5-6) ... Poussin ... developed his own version of classicism ... The reason ... was a desire to give a more enduring substance to ... [his] fascination with the paraphernalia of antiquity. What once captivated Poussin may now leave most people less than indifferent, but the formal perfection of his art endures. It also suggests that 'purism,' when caught up in a larger form, means pure romanticism (p. 7).

While Drexler recognizes the occult romanticism of the Glass House's purity, and the harmony between its inner and outer landscapes (the significance of which will become clear), he regards the painting as a mildly perverse, "minor punctuation of space," whose concerns with classicism and the "paraphernalia of antiquity" are presumed, in these modern times, to leave one "less than indifferent." Like Kipnis, he does not attend to the painting's semantics within the iconography of the Glass House, focusing instead on its attitude and style.

Similarly, for Vincent Scully (1986) Burial of Phocion reflects Johnson's devotion to "aristocratic" elegance in design.

Johnson's tastes and methods ... have remained fundamentally classicizing in character ... the Burial of Phocion $\ldots$ is not there for nothing. Its geometric structure and calm, aristocratic theme represent the heart of Johnson's artistic aspirations ... the Glass House [is] of all Johnson's works at once the most personal and universal ... the Glass House is the heart of what Johnson believes in (pp. $6-8$, italics added).

It is not there for nothing. Scully knows that a connoisseur as sophisticated as Johnson-and a designer as notoriously fastidious-could not have made such a pointed choice lightly. But 
his explication fails to satisfy, as the canvas was by no means the only-or the best-representation of refined classicism or aristocracy within the independently wealthy architect's means. At the same time, Scully's iteration of the word heart intuits a deeper relationship between the Glass House and the painting within it: it summons signification.

Nor can we simply conclude that Burial of Phocion was meant to be a symbol of enduring artistic genius, for its painter was hardly as popular then as he is today. The contemporary surge of interest in Poussin is credited to the unprecedented retrospective of his work at the Louvre in 1960 and to the scholarship of the art historian Anthony Blunt (1967), who curated the exhibition. ${ }^{3}$ One of Blunt's more controversial views-that Poussin's work contains all manner of clues and iconographic symbols that require decoding for true appreciation-has been challenged on the grounds that it was overly informed by (the former Sir) Blunt's more notorious occupation during his appointment as Surveyor of the Queen's Pictures-that of Soviet spy. Still, most would agree there is more to Poussinthe man, and the art-than meets the eye: "It is the nature of [Poussin's] temperament and beliefs that seems to become more, rather than less, mysterious the more we see, the more we read" (Haskell, 1995, p. 44).

Is there something about Poussin-and the enigmatic privileging of Burial of Phocion - that might attract a psychoanalyst, as well as a spy? Might a psychoanalytic approach to decoding the problem-or the puzzle-of the Poussin be as biased as a spy's? As dream-interpreters, sleuths, or spies, let us be curious about the "unconventional" installation of a seicento Old Master in a Modernist exemplar, keeping in mind the masking of objectionable realities by dreams-within-dreams. By examining Burial of Phocion in the context of the life and career of its painter, Poussin, by setting the painting and its painter's biography within the landscape of Johnson's political, cultural, and aesthetic concerns, and by privileging Johnson's own words over those of his commentators, I will argue that Johnson achieves the veiled displacement of vital, highly problematic narratives at the core of his identity onto an unassuming, generic "work of art." If this was indeed Johnson's conscious or unconscious strategy, then the painting's passing, in the face 
of its consummately honored situation, as little more than "a minor punctuation of space" testifies to its success.

As chronicled in Plutarch's Lives, Phocion (c. 402-318 BCE) was a venerated Athenian general who was convicted of treason and sentenced to death by drinking hemlock, and then disallowed a ceremonial burial in Athens (Plutarch, 1909). The painting shows the draped corpse of Phocion carted unceremoniously down a country road, in rude contrast to the peaceful, even idyllic landscape. Poussin depicts him thus disgraced, his corpse banished from the city. And so the painting immediately sounds the theme of exile, a theme encountered elsewhere at the Glass House (Tutter, 2011; Tutter, in press). But before we trace the path of Phocion any further, we must first examine aspects of Johnson germane to his relationship to Phocion, and to his painter, Poussin.

\section{An Accidental Architect}

Johnson once described himself as an "architect only by accident" (Johnson, 1979, 108). The myth of the lesser artist is critical to the explication of Johnson, whose constant selfeffacement served to enhance and propagate his perception as an inferior designer, a shameless imitator. His fear that he was not creative or original enough to be a true artist-or form giver-would burden him throughout his life. The following glimpses illustrate his resultant admiration and envy of those who had the gifts he thought he lacked: in essence, inspired ingenuity, and a resultant independence from style.

It is clear from a few names what integrity and nonfashionableness really mean. Lou[is] Kahn and Mies van der Rohe are way outside the world of fashion. And do we not admire them all the more because of it? (Johnson, 1979, p. 146).

I can hardly say how much I admire [Paul Rudolph's] work. I am very jealous of him-I hate him, and it's respectfully reciprocated ... But when [his] house came out, I was green with jealousy . . . It is all so ingenious, it hurts (p. 93). 
It is obviously not for me to make the awesome piles of Le Corbusier nor have I the splendid discipline of a Mies van der Rohe (p. 248).

At times, Johnson could elaborate a contemptuous, sardonic attitude to guard against feelings of jealousy and inadequacy; on the surface this could seem like a capricious changing of taste. Here, see how he rejects Eero Saarinen out of hand:

I do not like Saarinen's work at all. ... You should see the new ones at MIT or Idlewild [Kennedy International Airport]: there you have the bird that really could not get off the ground! (pp. 109-110).

only to admit, in the following, very different feelings.

I remember feeling very inferior [to Saarinen]. He was so much older than I was architecturally. . . . He could very well have been my teacher and I would have loved it. . . I l looked up to him as my senior ... (Stern, 2008, pp. 100-101).

Johnson's devaluing self-identification as derivative disciple served to preserve his subjugated attachment to his mentor, Mies van der Rohe, a relationship that shielded him from feelings of worthlessness, isolation, and fragmentation (Tutter, in press). Johnson's confused feelings-inferior, not inferior-toward Saarinen, and his evident longing for his mentoring suggests that for Johnson, the wished-for, idealized teacher-student relationship could also serve to stave off painful interrelated feelings of inferiority and envy. Of course, another way to ward off envy, alongside contempt and dependent attachment, is by appropriating its object-that is, by copying.

Feeling that he could not $d o$ as well as he could know, Johnson was far more confident about his art-historical abilities. Many have noted his incessant referencing-some questioning its veracity.

Johnson cites his sources like a historian ... Of course, he may have identified these sources after he did the 
designs. Even Johnson concedes that. What matters is that he seems compelled to cite influences (Lewis \& O’Connor, 1994, p. 14).

Others see Johnson's preoccupations with historical attribution as compensating for a lack of talent. Indeed, much of the discourse around Johnson accepts at face value his own characterization of himself as a derivative designer or copyist—such as Kipnis (1996), who identifies Johnson's compulsive historicism as a modus operandi, a self-serving rejection of originality:

... no one has ever denied [Johnson's] mastery of fashion ... A genius for fashion [however] is not a gift of originality ... Throughout his career, Johnson has not only been conspicuously unoriginal, he has, by virtue of his habitual rostering of references, positioned himself against the myth of architectural originality (p. 10).

It is certainly true that Johnson took refuge in the safety of formulaic style. One of the most important promoters of modernist architecture, Johnson is credited with having a critical role in bringing European Modernism to the United States. Further, he closely modeled his early work on Mies van der Rohe's interpretation of Modernism, justifying his receptive apprenticeship by repeatedly quoting Mies's dictum-it is better to be good than to be original.

Yet all evidence indicates that Johnson was not "against the myth of architectural originality"-he wholeheartedly ascribed to it, going so far as to consider it the grail, the definition of genius in design. The architect Peter Eisenman sensed that "words attempt[ed] to cover the fragility of Johnson's own uncertainty about himself and his own art" (Eisenman, 1979, 20); Johnson's imitative emulation of idealized artists served the same function. I suggest that Johnson's "rostering of references" was less a stand against the "myth of originality" than a defense against his believed failure to attain it-an indictment he nevertheless clearly and successfully encouraged. Nor would he be satisfied by having a "genius for fashion": for him, fashion was the antithesis of both classicism and iconoclasm-the former a promise of enduring value, the latter a promise of immortal genius. And in his eye, only an iconoclast became a classic. 
Drawing on the postmodern critique of the modernist myth of the original, ${ }^{4}$ the critic Craig Owens (1978) argues that Johnson's historicism acted to dissolve the original/nonoriginal dichotomy. He observes that in Johnson's 1950 essay introducing the Glass House,

Johnson effectively turned the popular conception of architectural modernism as anti-historical inside out to reveal a fundamental historicity at the heart of modernist practice (p. 81) ... Thus, it no longer makes any sense to ask whether the glass house is original or derivative (p. 85).

Owen's argument is elegantly and persuasively made, drawing, as it does, on the powerful postmodern critique of the modernist myth of the "original" as avant-garde (e.g., Krauss, 1986). And yet the doubtful Johnson clung to the polarity between "original" vs. "derivative" architecture, and to his unflattering self-assigned position within it. He did not, as one might predict, even consider himself a particularly good copyist.

Yet-and paradoxically-Johnson did believe that one could be original via "copying," allowing this for Marcel Duchamp, who laid bare the dialectics of appropriation in arthistorical discourse. Indeed, Johnson considered Duchamp "the greatest intellect in the twentieth century" (Baryle \& Zybach, 2003, p. 52), possessive of an unqualified, subversive kind of genius he could not locate in himself. Of note, after a relatively brief career as an artist, Duchamp directed most of his efforts toward championing the art of others; his role as the premier cultural tastemaker of the twentieth century was paralleled perhaps only by Johnson's. It thus may be inferred that Johnson somehow had a stake in maintaining a personal myth of inferiority, a position that I suggest may be understood as masking other, more positive attitudes toward himself, such that his appreciation of Duchamp was a projection of his own, disavowed gift. Likewise, his constant protests to the contrary"it is obviously not for me to make the awesome piles of Le Corbusier," "I wasn't a form giver like Mies," "I don't think I am a big time original architect," "I'm no Frank Gehry" — can be seen as a compulsive, iterative negation of his conscious or 
unconscious sense of talent, originality, or even genius. I shall propose that this "accidental architect's" underappreciated, possibly prohibited and certainly concealed qualities of goodness and greatness found displaced representation in Burial of Phocion: both in the figure of its painter, Poussin, and in the figure of his subject, Phocion-called, in Plutarch's Lives, "Phocion the Good".

Let us first consider Poussin.

\section{The Scholar's Cloak of Erudition}

Although at first glance Nicolas Poussin (1594-1665) may seem an unlikely figure of significance for Johnson, a second glance suggests otherwise. ${ }^{6}$ Being deeply read in art history and particularly interested in the artists he collected, it may be safely accepted that Johnson was familiar with the basic facts of Poussin's biography, certain aspects of which may have been especially meaningful, and may have factored in his choice to honor Poussin's work within his own.

Nicolas Poussin was born near the Norman town of Les Andelys, where, unlike many of his provincial class, he was the beneficiary of a sound classical education. He is said to have discovered his métier when he met Quentin Varin, a minor Mannerist painter who recognized Poussin's talent and encouraged him to pursue it (Thuillier, 1995). While he was studying painting in Paris, Poussin's work caught the eye of the poet Giambattista Marino, who arranged for Poussin to join him in Rome, where he introduced him to patrons and procured for him his first commissions. At the time the invitation of a foreign painter to Rome was an exceptional gesture, widely interpreted as attesting to the appreciation of Poussin's rare gift (Haskell, 1995; Blunt, 1967).

This story calls to mind Johnson's capacity to attract those who could perceive his talent and further his career. Johnson met Alfred Barr at his sister's commencement from Wellesley College, where Barr taught art history; like minds, they developed an intense, lifelong friendship, one that involved no small degree of mutual admiration and respect. ${ }^{7}$ In 1930 , Barr, now the founding director of the Museum of Modern 
Art (MoMA), brought Johnson to New York to spearhead a new department of Architecture and Design at MoMA-before he had graduated from Harvard, and before he knew much about architecture. To prepare for his first assignment-the presentation and promotion of the burgeoning movement of European Modernism to an American audience-Johnson, Barr, and the architecture historian Henry-Russell Hitchcock traveled across Europe, visiting architects in their studios and viewing their buildings. Johnson recalled:

Our trips together were an education to me ... Of the three of us, Russell had the great eye. He was a supreme historian ... Alfred was the resident ideologue . . He was the one who shaped our thinking . . I I was still somewhat of a student at the time (Hitchcock \& Johnson, 1995, p. 14). ${ }^{8}$

This tutelage bore fruit in The International Style, Johnson's groundbreaking 1932 MoMA exhibition and accompanying monograph (Hitchcock \& Johnson, 1932).

When in 1624 Poussin arrived in Rome, he too immersed himself in scholarship, making a careful study of anatomy, Renaissance painting and sculpture, and Greek and Roman statuary. He swiftly earned respect for his meticulous research into ancient modes of dress, armor, custom, and architecture, the details of which invested his classical and biblical subjects with conviction and authority. This scholarly rigor impressed Roman connoisseurs and soon enough their learned counterparts back in France-in particular, the important patron and friend Paul Fréart de Chantelou, for whom Poussin painted his second self-portrait (Christiansen, 2008a, figure 2). No less than Poussin, and despite his proclivity for the modern, Johnson was also a superb antiquarian, and was thus well suited to appreciate Poussin's cerebral scrupulosity and classical preoccupations.

The traditional critique of Poussin is strikingly similar to the traditional critique of Johnson, revolving around the question of "genius" and its attendant concerns: the problem of the original; the problem of the intellectual; and the problem of style. 

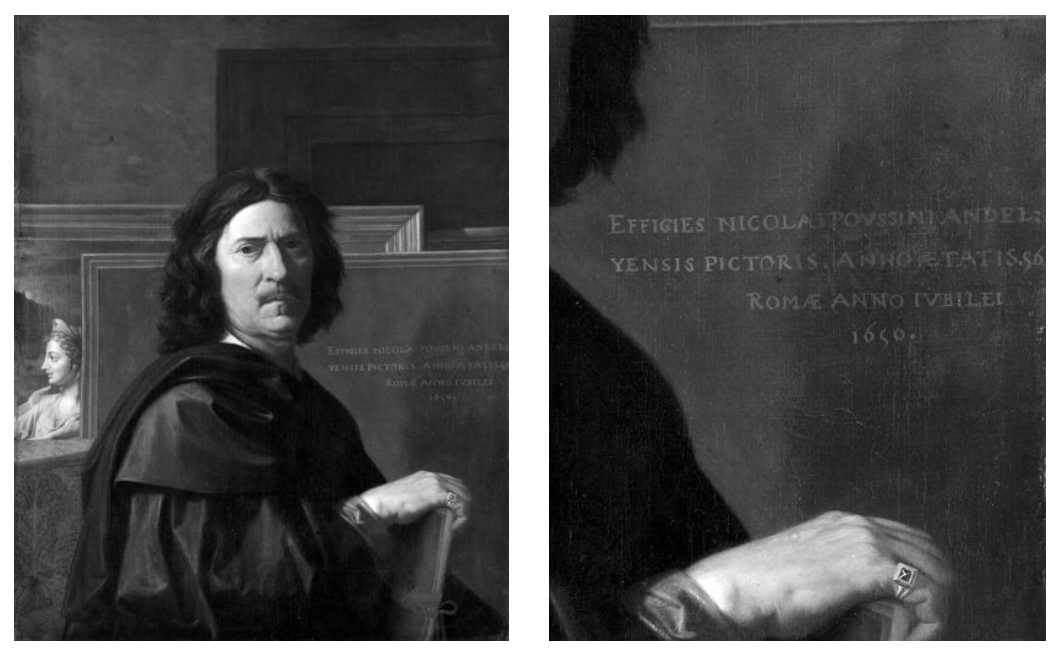

Figure 2. left: Self Portrait, N. Poussin, 1650, Museé du Louvre, Paris, France. right: detail, inscription reads "EFFigies nicola poussin Andelynsis". Image () Réunion des Musées Nationaux/Art Resource, New York. Used with permission.

It was for the antiquarian erudition and deliberation Poussin brought to subjects of great import, whether biblical, historical, or based on Greek and Roman literary sources, that he was admired by his two principal seventeenth-century biographers (Christiansen, 2008b, p. 9) ... Not everyone [however] felt ... that the scholar's cloak of erudition guaranteed artistic greatness, or that a learned viewer had a corner on critical appraisal (p. 12).

In this context, the tacit function of "the scholar's cloak of erudition" is to provide a cover for a lack of "artistic greatness," usually defined as innovative creativity-in other words, independence from school, style, teacher or tradition (Kris and Kurz, 1934). John Ruskin objected to Poussin accordingly.

The landscape of Nicolo Poussin shows much power, and is usually composed and elaborated on right principles, but I am aware of nothing that it has attained of new or peculiar excellence; it is a graceful mixture of qualities to be found in other masters in higher degrees (from Modern Painters (1843), quoted in Wright 2007, p. 282, italics added). 
This dismissal exactly prefigures those that find Johnson lacking in originality, attaining no "new or peculiar excellence". Perhaps inadvertently, the normally reverential Blunt echoes Ruskin.

Poussin's [art] is the opposite of Rembrandt's. It never relies on those flashes of intuitive genius which make every line drawn by the great Dutchman seem loaded with meaning, even if the method by which the meaning is expressed seems inexplicable. Poussin, on the contrary, could, one feels, have explained in words why he used any particular device, and have justified its use with solid reasons. Rembrandt needs no such justification. (Blunt, 1967, p. 267).

Even if well intended, this sort of comparison cannot fail to generate clichéd value statements (Carrier, 1993): the "inexplicable" Rembrandt, possessive of "intuitive genius," "needs no justification"; like Johnson, Poussin is, on the other hand, reducible to quotidian "words," "device," and "solid reasons" (p. 267). Imagine the sympathy Johnson might have had for Poussin, saddled with the indignity of comprehensibility, hardly compensated for by the faint praise of intellectual or stylistic brilliance, assessments that are tenaciously repeated in the literature. ${ }^{9}$

Johnson and Poussin have also been charged with an excessively restrained, mannered elitism, their work accessible only to those who can appreciate the subtlety and nuance of its recondite references. Indeed, Poussin expected his patrons to participate actively with his work by "devoting the most careful concentration to it," specifying that they "read'-his own word-paintings in which nothing had been neglected or left to chance" (Haskell, 1995, p. 46), ${ }^{10}$ and Johnson's contempt for the pedestrian and the vulgar was no secret. But while Poussin was well known for the breadth and depth of his classical references and while Johnson's work is admittedly similarly densely packed with historical and literary quotation, for both, emotional impact, communicated by instantly knowable means, trumped intellectual allusion or even aesthetic appeal. In anticipatory empathy with the viewer, Johnson's primary aim was to achieve the overwhelming affect, the jouissance he 
first experienced from architecture when, at the age of 13, he wept at the cathedral at Chartres: "all great architecture is the design of space that contains, cuddles, exalts, or stimulates the persons in that space" (Johnson, 1979, p. 262). Likewise, Poussin's canvases, if somewhat calibrated or controlled, are suffused with feeling, carefully constructed with an eye toward "the effect produced on the mind" (Denio, 1899, p. 215).

Poussin's landscapes in particular can "be appreciated with little or no literary knowledge" (Christiansen, 2008a, p. 21). Herein lies a nodal point for these two outwardly disparate artists, for jointly expressed by Poussin's Arcadian landscapes (Pace 2008), and by Johnson's continual reshaping of his estate toward an idealized vision, is the romantic wish for wonderment and retreat in an idealized nature, transformed into art. ${ }^{11}$ Might this relate to their having spent their formative years on farms? In particular, Johnson and Poussin shared a predilection for trees:

As essential instruments in the construction of space, [Poussin's] great oak trees serve to contain a scene, to provide contrasts of shadow and light, and to create depth ... (Cavina, 2008, p. 47).

Trees are becoming the basic building material of the [Glass House]. The framing of the view, the repoussoir. The accents are all done by trees. (Johnson, quoted in Lewis and O'Connor, 1994, pp. 34-36).

At the Glass House, Johnson created a groomed park by painstakingly editing, tree by tree, a forest of secondary growth, considering the placement and form of each individual tree left standing, and, like Poussin, the "contrasts of shadow and light" they would impart. But perhaps the greatest aesthetic resonance between Johnson and Poussin is their masterful embellishment of the beauty of natural landscapes with the grandeur of manmade form: "[the art historian] De Piles considered the use of architecture as an essential element in 'heroic landscape,' and considered Poussin its supreme exemplar" (Pace, 2008, p. 85).

There was thus ample opportunity for Johnson to recognize aesthetic and narratologic aspects of himself in the personage 
of Poussin, including the common intellectual, classicizing, and stylistic concerns that have interfered with their critical reception. On the other hand, if any kinship Johnson might have felt with Poussin's genius were forbidden, aligning himself with Poussin as an underappreciated artist would have been a convenient means to deny it.

The authentication of Johnson's Burial of Phocion, one of several known copies, was controversial even before Johnson purchased it. ${ }^{12}$ Some, including Barr and the Poussin scholar Walter Friedländer, believed it to be genuine, while Blunt had his doubts (Schulze, 1994, p. 234). That Johnson installed it in the Glass House, regardless-and kept it there-speaks to his acceptance and appreciation of something that may or may not be what it claims to be. Might this ambiguous provenance-the painting quite possibly being a competent, but relatively worthless copy-represent and comment on Johnson's disturbing uncertainty around his own worth and authenticity? In other words, was he, too, "the real thing," or just a "copyist"—a "real architect," or only an "accidental" one? Adding to the indeterminacy of the painting's worth, in Poussin's time, copies of his and other important seicento paintings were routinely commissioned and highly valued (Franken, 2005). Despite the greater value placed on the hand of the master, the reputation of the named copyist, frequently approved or even chosen by the artist, factored into the appraisal of the reproduction: even a copy—and its copyist—could be legitimate. Johnson's distrust and disavowal of his own worth, and the simultaneous entertainment of potential greatness, is thus symbolically encapsulated not only by his choosing a Poussin, but also by his choosing a Poussin of indeterminate authentication.

Ironically, Johnson may have also identified with the painting's ruination. His devotion to the New Canaan Burial of Phocion is countered by the fact that it is woefully unprotected as installed. Surely it is not coincidental that, in marked contrast to the care given to the rest of his collection, the painting he prized so highly was kept in an environment in which harsh sunlight and variations in temperature and humidity have led to its rapid deterioration. Johnson fully understood the consequences. ${ }^{13}$ As such, the inexorable ruination of the fragile painting, despite multiple restorations, resonates with the 
theme of vulnerable exposure, embodying his own mortality and the failure of power or greatness to grant immunity from it-all multiply determined themes at the Glass House (Tutter, 2011; Tutter, in press). More darkly, the painting's deterioration may be construed as an effigy, a symbolic punishment for exhibitionistic display and grandiose strivings-which leads us back to its executed subject, "Phocion the Good."

\section{Paths of Exile}

Johnson's interest in Phocion must be understood in the context of his immersion in the classics, Phocion's brief but celebrated story being one of Plutarch's Lives. ${ }^{14}$ Poussin, too, was familiar with Plutarch. He broke with the convention of his time by painting subjects of his own liking, choosing not to rely on the specifications of papal or royal commissions (Carrier, 1993) - a degree of freedom analogous to that allowed by the design of an architect's own home. The manner in which Poussin depicted Phocion was also his choice, and was moreover uninformed by precedent, as Phocion had not before been the subject of a major canvas (Sauerländer, 2008). In Burial of Phocion, Poussin decided to depict Phocion as a corpse, en route to his disgraceful burial outside of Athens. He is thus presented in the process of exile.

It was Blunt (1967) who first pointed out that, although he had long made his home in Rome, while painting the Phocion cycle, ${ }^{15}$ Poussin worried that the political upheaval in France-the conflict known as the Fronde-would prevent him from returning to his mother country. It had already had an impact on him from afar. Olson (2002) describes how the brewing civil war in France and the rise to power of Cardinal Mazarin resulted in "the political disgrace of Poussin's chief patron in France, Sublet de Noyers," the "termination of [his] system of patronage," and "the fall from political favor ... of those loyal to him," including Poussin's friend and patron, Chantelou (p. 75).

Since Sublet had been responsible for the honors Poussin had received from the French crown, the absence of 
Sublet from court had a direct bearing on the painter's decision to remain in Italy . . . Poussin relied on metaphor and myth to express his joy, anger, and despair over the events surrounding Sublet's disgrace. He compared Sublet's plight to that of Aeneas, wandering in exile . . . (p. 75)

Poussin may himself have identified with Aeneas in exile: in 1645, his house in the Tuilieries was, in "an explicit affront to the authority of Sublet," confiscated by the queen, a "decision [that] was justified by hearsay evidence that Poussin had no intention of returning to Paris." In addition to his apparent "personal identification with the disgrace of Sublet de Noyers," he explicitly "expressed his sense of being persecuted [and] lamented that he was being exiled from his place of birth" (pp. 75, 76). And in a letter to Chantelou from this period, he protested:

Now that I long to return and enjoy the sweetness of the land [patrie] where each of us desires finally to die, I see myself chased out ... Is it possible that there is not one person who wishes to defend my rights? Do the French have so little feeling for their nurslings who honor their country and fatherland [leur pays et leur patrie] by their virtue? (p. 76)

In his consideration of the paintings, Démoris (2008) proposes that Poussin, "may have felt a certain affinity for the ancient Greek," whose banishment from Athens was politically motivated (p. 94). Then again, Poussin may have felt an exile long before the Fronde.

Poussin's father disapproved of his son's artistic inclinations, and wanted him to be a lawyer, placing on Nicolas his hopes for the restitution of the family wealth that was depleted while he was fighting in the Holy War. Nevertheless, at the age of eighteen, Poussin left home to study in Paris, and only a few years later made his home in Rome. Might his sense of exile-quickened no doubt by the unrest in France-have been rooted in an emotional, as well as a physical distance from his 
parents? It was his gift that took him so far away, for at the time Rome was where art truly flourished.

Johnson had his own reasons to sympathize with the exiled Phocion. As an infant and young child, he endured prolonged separations from his parents, and often spoke of having been left all alone as an adolescent. Moreover, from a young age, he and his siblings were made to spend their nights, year-round, outside, on a sleeping porch, an experience which may have felt like a banishment (Tutter, in press). His early sensitivity to manipulated landscape and architectural form seems to have provided some solace. During one lonely summer in Paris,

again, I went all alone . . . But everyone was surprised that [my parents would] let a twelve-year-old boy wander around. So I found the Buttes Chaumont . . . still the greatest romantic park in the world (Stern, 2008, p. 20).

[The Parc des Buttes-Chaumont] has fake caverns, and little bridges, a little fake mountain, and a little lookout on top ... (Lewis \& O’Connor, 1994, p. 142).

Pictured in the deep background of Burial of Phocion is a classicizing Greek monument, the ancestor of the "little lookout on top" in the Buttes Chaumont - a detail that could not have failed to add to the painting's appeal (Fig. 3) — and perhaps a reminder of time spent alone, apart from an indifferent family. Another cause for Johnson to feel exiled from both family and society was his homosexuality. Tormented by crushes and painfully alienated in college, he struggled to adhere to the absolute morality and virtue espoused by Plato, his first intellectual infatuation. His father disapproved of his son's sexuality, and his proclivity for art and design. Some things never change: like Poussin's father, Johnson's father had wanted him to be a lawyer (Schulze, 1994, p. 40).

As an adult, Johnson suffered a series of far more public experiences of exile when his former pro-Nazi activity was exposed in William Shirer's Berlin Diary, in which he was named as "an American Fascist" and alleged Nazi spy (Shirer, 1941, p. 215; Schulze, 1994, p. 151). Johnson had spent only a few years 

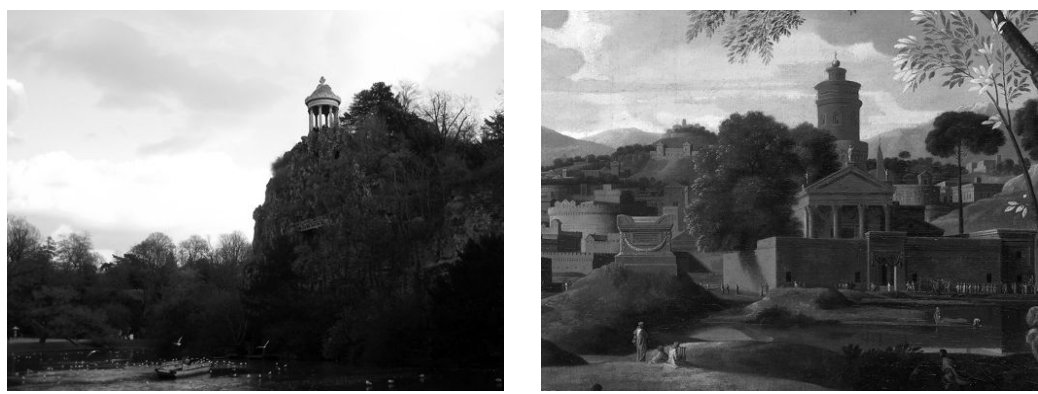

Figure 3. left: Temple de la Sybille, Parc des Buttes Chaumont, Paris; Baron Georges-Eugène Haussmann, 1864-67. Photograph, kind courtesy of Sébastien Bertrand. right: Burial of Phocion, detail.

as a successful curator under Alfred Barr when he abruptly left his post at MoMA in order to dedicate the next several years to poorly considered and ultimately disastrous political strivings. In the mid-1930s, he lived in Berlin, enthusiastically reporting on the rise of the Third Reich for extremist right-wing publications at home. He abandoned Hitler and left Germany-once a liberated sexual haven for gay men-only when it became a more overtly dangerous place (Schulze, 1994). Swinging erratically from far right to far left, Johnson had no sooner returned to the United States when his attraction to charismatic extremists led him to embark on a road trip-cum-pilgrimage to Huey Long (the "Kingfish") of New Orleans, offering up his dubious political experience in his service. The reading material he brought along for the ride included the requisite Machiavelli, Nietzsche, Shakespeare ... and Plutarch's Lives (Schulze, 1994, p. 116). A subsequent highly publicized attempt to found a new National Party-intentionally anti-ideological and lacking a platform—was lampooned in the press.

Johnson's serial political catastrophes would have been more amusing did they not reflect his political naiveté, grandiosity, poor judgment, and emotional instability, earning him broad ridicule. He had no sooner reoriented himself and taken a far more prudent course, reentering Harvard in 1938 to study architecture, when he was disgraced by the publication of Berlin Diary. Word spread quickly. Although he was known to have helped several Jewish architects and scholars gain passage to the United States, promoting their work and 
finding them faculty positions, once friendly faculty and fellow students grew aloof. After graduating from architecture school, Johnson was drafted, but his hope for an officer commission was curtailed when Army intelligence was alerted to his political history. Facing fresh ostracism, he was demoted to menial duties, and found himself shunned by the elite society he had once moved in: “The situation there,' he commented later, 'with all my old friends looking on me with suspicion was the hardest thing I have gone through in years"' (Schulze, 1994, p. 162). If Johnson was sensitized to the pain of disgraced exile by early experiences of banishment, in some ways, he was compelled to recapitulate them.

In Schulze's opinion, Johnson's attraction to the Nazi theatre of power was principally aesthetic. Yet one cannot minimize his affinity for the power and dictatorial authority implicit in the brute monumentality of the Nazi aesthetic. Nor can his endorsement of Hitler and collusive white supremacist statements be discounted as innocent or abstracted dabbling, for he was alarmingly ready to absorb, reflect, and disseminate Nazi ideologies, regardless of his actual commitment to them (Ockman, 2009). A 1939 letter in Johnson's FBI dossier reads:

I was lucky enough to get to be a correspondent so that I could go to the front when I wanted to and so it was that I came again to the country that we had motored through, the towns north of Warsaw. . . I I went through the same square where we got gas and it was unrecognizable. The German green uniforms made the place look gay and happy. There were not many Jews to be seen. We saw Warsaw burn and Modlin being bombed. It was a stirring spectacle (Schulze, 1994, p. 139).

Nazism provided a mighty movement and a "Great Man" for Johnson-who had long eschewed Plato for Nietzsche-to identify with and follow, just a few years before he cast his lot with Mies (Schulze, 1994; Ockman, 2009). Still, it is hard to fathom how Johnson, who was homosexual and who assisted Jewish architects in reaching the United States, could have endorsed Hitler's explicitly murderous agenda, unless one postulates 
that it involved a degree of self-punishment or identification with the aggressor.

Johnson's colleague and friend, Terence Riley, ${ }^{16}$ posed Johnson a question at the core of this troubled period.

I found occasions in the last years of his life to quietly discuss those years ... I asked, how could he have left the museum [MoMA], an institution that had given his life so much direction and offered him so much accomplishment? He responded, after reflection, 'My father thought I was a mama's boy, which I was. I never got a paycheck from the museum, so he thought of it as volunteer work, something women did. I felt I had to do something else' (Riley \& Sacks, 2009, p. 66).

He may have also felt that he had to do something great. Johnson's response to Riley allows his infatuation with Hitler and other extremists to be framed less as ideologically or aesthetically motivated, and more as an effort to enhance his sense of self-worth, potency and masculinity-in his father's eyes, and perhaps his own. He emphasized one friend's steadfast loyalty during his most difficult times.

My only friend was Alfred Barr, who never, never deserted me. Never wouldn't see me. [Despite my politics] he never, never stopped loving me, nor did he break off our friendship (Stern, 2008, p. 67).

The following story gives playful, but meaningful testimony to Barr's devotion.

My best chairs fall down when a heavy man teeters back in them. My worst one was so low I could never get out of it myself ... The Barrs [Alfred Barr and his wife] had it in their living room until the end (Lewis and O'Connor, 1994, p. 174).

In a press release announcing the restoration of Burial of Phocion, The National Trust highlights that it was Barr that recommended the canvas to Johnson in $1945 .{ }^{17}$ It found its 
place in the Glass House several years later. Reciprocating the permanent presence of Johnson's chairs in Barr's home, the permanent presence of Barr's painting in Johnson's home may be understood as an act of grateful homage to Barr-and an emblem, perchance, of his steadfast friendship in the face of disgrace.

Like Barr, Johnson's friend Lincoln Kirstein, founder of the New York City Ballet, was outraged by, but ultimately forgave Johnson's unquestioning embrace of Hitler-all the more remarkable since Kirstein, unlike Barr, was a Jew. Kirstein was another invaluable source of mirroring affirmation for a man who had suffered from too little: just as Barr stood by (and sat in) Johnson's chairs, "in Kirstein's eyes, Philip could do no wrong architecturally" (Schulze, 1994, p. 384). And, just as Johnson honored Barr by choosing the Poussin to display in the Glass House, he honored Kirstein by selecting a work by Elie Nadelman as its only sculpture.

Two Circus Women (1930) is a papier-mâché sculpture by Elie Nadelman, a Polish Jew who had lost his family in the Second World War and a sculptor whose work was determinedly championed by Kirstein after his suicide in 1946 (Haskell, 2003, figure 4). By placing this work in what was clearly destined to be a prominent building, Johnson fostered Kirstein's advocacy of Nadelman just as surely as Kirstein fostered Johnson's own career. ${ }^{18}$ The sculpture has received even less critical attention than Burial of Phocion; the only consideration of Two Circus Women within the context of the Glass House interprets Johnson's patronage of Nadelman as a shrewd, disingenuous gesture calculated to protect him from future accusations of anti-Semitism (Ockman, 2009). Yet Johnson may have also identified with Nadelman, who lived in exile in New York, where his work was received far less enthusiastically than it had been in Europe.

Two Circus Women - a same-sex couple joined at the hipcan also be read as honoring Johnson's relationship with David Whitney, Johnson's partner, who lived with him at the Glass House for almost four decades. The benevolent attitude and larger-than-life scale of its fused figures suggest that they can alternatively be construed as representing the dual personages of Barr and Kirstein-idealized surrogate parents-recursively 

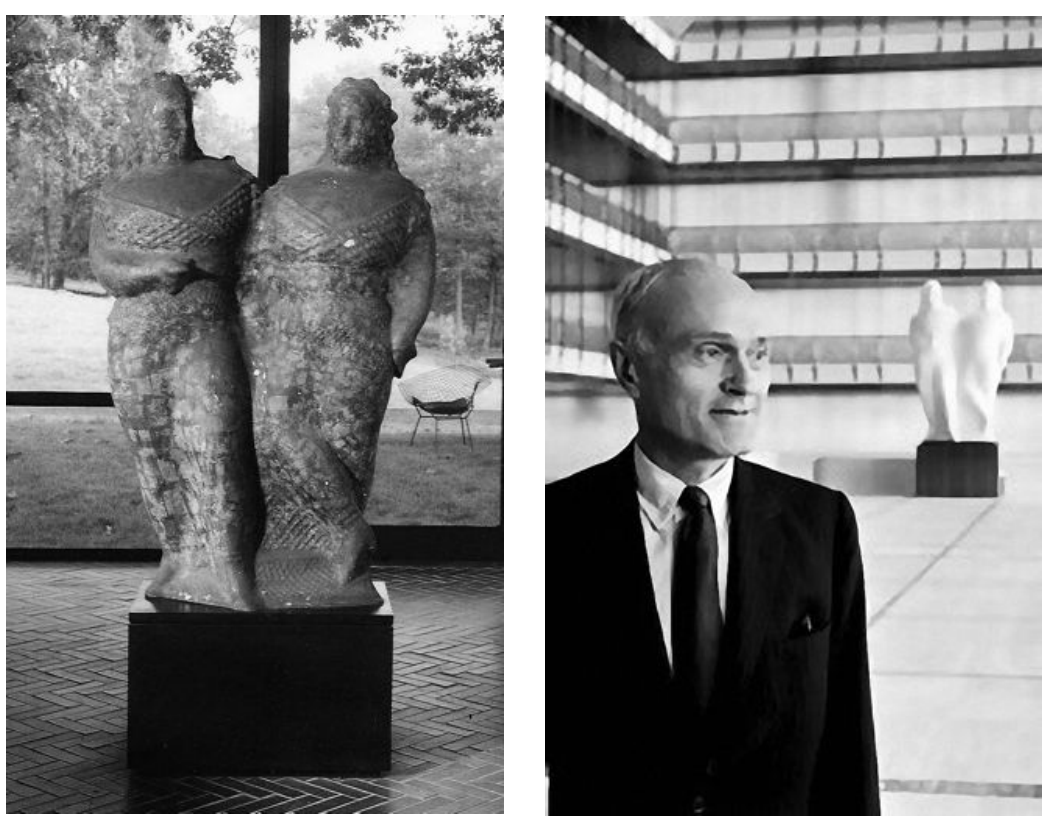

Figure 4. Two Circus Women, E. Nadelman, 1930. left: original papier-mâché version in the Glass House. Photograph, courtesy Sotheby's and the Philip Johnson Glass

House, National Trust for Historic Preservation. right: Philip Johnson with the large-scale marble rendition of Two Circus Women installed in the lobby of the New York State Theatre. Photograph, courtesy John Rooney.

iterating their respective signification by the only works of art in the Glass House. ${ }^{19}$ Their presence in Johnson's home is linked to the two devoted advocates who not only returned his respect and admiration, but gave him something he had perhaps never before received-unconditional love. This love was symbolized by Johnson's acceptance and honoring of a contemporary work by an exiled sculptor with a questionable reputation; and an Old Master of questionable authenticity, of Phocion, a questionable hero. Let us now take a closer look at the particular circumstances of his exile.

\section{Plutarch's House of Mirrors}

After a long military career distinguished by multiple successful but costly campaigns against the invading Macedo- 
nia, Phocion, a highly respected general of Athens, openly opposed yet another expensive maneuver against the more prosperous and better-equipped country. Instead, he argued in favor of the peaceable occupancy he had negotiated with Philip, King of Macedonia. According to the dictate of King Philip, who trusted and respected Phocion, the conditions of this agreement specified that the venerated Athenian would be appointed ruler of Athens. However prudent or wise such an outcome may have been, Phocion's political rivals leapt at this opportunity to turn public favor against him; accusing him of opportunism and treason, they decried his plan as a betrayal of Athens. A show trial resulted in Phocion's conviction and execution for treason. His dignity in the face of public disgrace and impending death only served to enhance his posthumous reputation, for the tide of public opinion would shift again. According to Plutarch (1909),

a very little time and [the Athenians'] own sad experience soon informed them what an excellent governor, and how great an example and guardian of justice and of temperance they had bereft themselves of. And now they decreed him a statue of brass, and his bones to be buried honourably ... (pp. 367-368).

Like Poussin before him, Johnson would have appreciated the parallels between Phocion's denouement and his own: he, too, was disgraced for supporting a dictator of a foreign country-appeased, like the King of Macedonia, by the annexation of foreign lands. Barr maintained that Johnson was never antiAmerican, stating that he "never, I believe, put the interests of another power above those of his own country" (Schulze, 1994, p. 163). In more recent musings on this issue-in what remains the only critical commentary on Johnson that takes on the subject of Phocion, albeit vanishingly briefly-Scully acknowledges just a bit more ambiguity, evidently feeling freer to do so since Johnson's death.

And here is Johnson, a kind of would-be oligarch, a farright wing politician who leaves New York (perhaps in imagination banished from it) and is now sitting out in 
the country in what can be thought of as a self-imposed exile. Plutarch clearly felt that [Phocion's] execution was unjust. Maybe Philip did too, and perhaps he felt the painting offered, if not a justification, at least a kind of explanation of it all (p. 23).

While Scully's somewhat cryptic remark implies that Johnson identified with Phocion's exile, he stops short of allowing that any parallel that Johnson drew between himself and Phocion is necessarily a defiant, unrepentant one, in that Phocion's execution and exile-in Plutarch's eyes, and thus in Johnson's-was ultimately considered unjust. Consistent with an idealized identification with Phocion as innocent, virtuous, maligned and persecuted, Johnson appeared to believe he had done nothing wrong, rather, as he said, he "was on the wrong side. So we don't talk about that anymore. My enemies do, of course. That's a part of my life that I'd rather forget" (Lewis \& O'Connor, 1994, p. 33, italics added).

Poussin may have shared such a wishful affinity with Phocion; after all, he had spent less than two years in the house in Paris that Louis XIII gave him in return for his assumedly lifetime service as Premier peintre $d u$ Roi, before he returned to his beloved Rome with no real intention of ever returning to France. Démoris (2008) posits that the 1648 Phocion cycle "mark[s] the moment of Poussin's retreat from the historical stage," and that for Poussin

the political tumults of the Fronde seemed like a bad farce that derided its actors ... Grand history masks the petty maneuvering of private interests ... This disillusionment went hand in hand with a progressive abandonment of neo-Stoic morals . . Phocion embodies the futility of political heroism (p. 95).

Johnson made his own disenchanted exit from "grand history." But although he would fairly rapidly reestablish his respectability, he appears to have suffered from a palpable "futility" and wounding "disillusionment": the death of his own "political heroism." 
One could, and did, feel passionately about things, as about politics in the thirties ... It is a great help in life if one can feel passionately about things . . . I have no faith whatever in anything ... Where there are political passions, it is easier to have architectural passions (Johnson, 1979, p. 109).

I am not interested in politics. It perhaps comes from the fire that one had originally dying out somewhat ... (pp. 111-112).

One hears in this echoes of the rather jaded remove of a letter from Poussin to Chantelou in 1649, written on the occasion of the beheading of Charles I of England, in which he remarked, "It is a great pleasure to live in a century in which such great events take place, provided that one can take shelter in some little corner and watch the play in comfort" (Poussin, 1824, p. 395).

Having long given up on politics, Johnson seemed content to let his reactionary stance fade into the past and be forgotten, volunteering neither apology nor remorse for his Nazi allegiance until fifty years later-and then only when publicly challenged to do so by Michael Sorkin, an architecture critic (1978). Johnson may well have derived vindication from the moral that Lamberton (2003) argues Plutarch himself extracts from Phocion's tale: “in Plutarch's house of mirrors and true and false symmetries, a well-lived life can . . . be so maimed by history that few would perceive its genuine success" (p. 8). For regardless of his wisdom and benevolent intentions, Phocion had, in reality, parlayed Athens' defeat into his own success. And would Johnson not be tempted to identify with Plutarch's seductively forgiving portrait of Phocion,

shaped by [Plutarch's] manifest admiration for this oligarchic politician whose faults are carefully obscured behind constant displays of eloquent wit, and whose great crime Plutarch in effect excuses by understating it while turning its illegal and excessive punishment into high drama ... [Plutarch ends by] distancing his subject from any responsibility (Lamberton, 2003, p. 9). 
Given that Barr also knew Phocion through the lens of Plutarch's sympathetic eye, and given that Plutarch's Phocion and its hero had yet to be seriously reappraised by modern historians (in fact, not until Tritle 1988), Barr's recommendation of the painting may now be seen as conveying a similarly forgiving attitude toward his friend. And so the narrative of Phocion's narrative both mirrors and infuses the narrative of Johnson.

Great images have both a history and a prehistory; they are always a blend of memory and legend, with the result that we never experience an image directly. Indeed, every great image has unfathomable oneiric depth to which the personal past adds special color (Bachelard, 1958, p. 33)

In portraying Phocion as a disgraced corpse banished from Athens, Burial of Phocion literally positions him as traveling between his past, as a disgraced traitor, and his future, as an exonerated patriot. Poussin's image thus summons up all the ambiguity and flux of his inherently indeterminate state of exile, eloquently summarized by Edward Said (1994):

the exile exists in a median state, neither completely at one with the new setting, nor fully disencumbered of the old; beset with half-involvements and half-detachments; nostalgic and sentimental on one level, an adept mimic or a secret outcast on another (p. 149).

At the same time, Poussin's draping of the corpse renders Phocion fully unidentifiable and anonymous, and therefore a more receptive container for the viewer's projections. I contend that Johnson projected into the virtuous, stoic figure of Phocion the Good his own forbidden feelings of self-worth and grandiose strivings-feelings as badly damaged ("maimed by history") as Poussin was by the Fronde, what he termed "the malignancy of the century" (Olson, 2002, p. 77).

Just like Phocion, Johnson was also on the road toward repairing his ruined reputation. The Glass House was one of his first buildings, and the first to generate serious critical interestindeed it attained for its architect the renown that had eluded him in politics. With it, he also reclaimed his prominence in a 
world he had relinquished for politics-reincarnated, moreover, as a "real" architect, not an unpaid critic and curator. Johnson's rebirth was in fact a splendid entrance, heralded by his own prolix exegesis in "Residence in New Canaan." Kipnis (1993) in fact views the Glass House as a staged, brazen assertion of dominance.

[Johnson] knew that his Glass House would exercise an extraordinary power over the imagination of professional and layperson alike. More than most, Johnson the architectural curator and historian knew that history almost guaranteed the effect ... Johnson was dead right (pp. xiv-xv).

Johnson went on to consolidate his success with the design of museums, theatres and other highly visible commissions. His stated ambition—l'architecte du roi (Huxtable 1964, May 24) —was far more vigorously sought than Poussin's reluctant position as premier peintre du roi to the court of Louis XIII.

In a rare essay on the Phocion cycle, Lawrence Steefel (1991) observes that the art-historical literature has deemphasized the central narrative of Burial of Phocion, seeing it and its pendant painting as "noble landscapes of elegiac serenity without significant pathos, frustration, or alienating pain," whose "classicism ... speaks to the positive qualities of life and mind as against the sad story they enframe" (10-11). Concurring, Olson (2002) argues that "the plight of exile" was "central to the pastoral elegiac mode" of the Phocion cycle (225). Methodically explicating its "apprehension and despair," Steefel importantly reformulates Burial of Phocion as

a constricted pathetic image of abandonment and persecution, far more than it is the memorial of a great man . . . the Phocion paintings become as poignant an image of political and human alienation as Western art has to show ... [they] were meant to be a kind of common speech, noble in aspect and classical in composure but actualities none the less. Whatever goodwill may have prompted critics ... to honor Poussin in these paintings for his greatness as a painter more than for his greatness 
as a communicator ... has too often served to diminish the master's accomplishment by abstracting his reality into a contemplation of style (p. 14, italics added).

What Steefel decries as a skewed, reductive emphasis on style could not more precisely describe what Johnson's oeuvre has withstood, there being no better example than the conventional interpretation of the New Canaan Poussin as representing refined classicism and elegance-style. The critical elision within the Glass House discourse of the painting's actual narrative-its tragedy, its cruelty, its absurdity-may reflect a collective disavowal of the impact of Johnson's political sins on his life and on his work. Did this collude with Johnson's intent? Did he, too, "abstract his reality into a contemplation of style"? There can be no doubt that the understated, innocuous painting- - noble in aspect and classical in composure"-has proven an effective foil for the wrenching feelings I propose Johnson located in its stoic, ultimately romantic hero: banishment and exile, surely, and disgrace, but also prideful impenitence, wrongful persecution, and righteous indignation. In addition to the dilemma of Johnson's legacy as shameless copyist vs. great architect, the figure of Phocion also symbolizes, and thereby masks another wrenching question: was he a patriot-or a traitor? And, paradoxically, was "greatness" a transgression for Johnson, as great (or even greater) a transgression than his embrace of fascism, so great it had to be obscured in an obscure canvas?

In order to deal with these jarring, irresolvable realities and conflicts, I suggest that Johnson constructed a "personal myth" (Kris, 1956), outwardly perceiving and portraying himself as artistically inadequate and incompetent-a corpse, even ("the fire dying out")—while splitting off and projecting unacceptable inner feelings of greatness, strivings for power and remorseless ambition into acclaimed structures, in particular the acclaimed Glass House, and the ambiguous signifier on which its lens is focused, Burial of Phocion. Significantly, both could be disowned, if necessary, as mere counterfeits: the Poussin a fake, and the Glass House "a bad copy," as Johnson himself called it (Stern, 2008, p. 150). Johnson's duality of good and bad-the divina artisto vs. the lesser artist—may be more specifically understood as projectively identified with the devalued Old Master, Poussin, 
and the deposed hero, Phocion the Good. The transported corpse of Phocion crystallizes these dialectics, embodying the tense equilibrium struck between a reprehensible past and a refurbished future-and between inner positions of disgrace, disavowal, and dignity.

Built from a constellation of associative links and observations, the interpretative propositions put forth here remain, by definition, inferred. The strength of such conjectures rests on their internal consistency and ability to make persuasive meaning out of the material at hand. In a related study, I argue that the transparent Glass House contains a counterphobic representation of disgraceful exposure, and, via formal elaborations of Johnson's identification with Atreus, of royal strivings and exile (Tutter, 2011). In another study, I posit that the conflict between dependent attachment vs. fragmenting isolation, and its derivative, the tension between the artistic disciple vs. the divina artisto, are signified in physical, dynamic, and symbolic ways throughout the Glass House (Tutter, in press). Here, I construe Burial of Phocion as contributing to the overdetermination of these motifs, restating and synthesizing them within a condensed array of interlacing points of contact between Johnson, Poussin, and Phocion. It remains wholly unclear whether Johnson was conscious of all of the manifold layers of meaning that Burial of Phocion may have had for him, although as shall soon be evident, he was aware of at least some. Whether consciously disavowed or unconsciously repressed, his stated wish to extinguish any clear connection to his grievous past is consistent with his silence around the painting- " $a$ part of my life that I'd rather forget." And so a terrible effigy of shame, alienation, and exile is transformed into a classical elegy of sacrificed nobility. Symbolized, idealized, romanticized: like a dream within a dream, the tragic figure of Phocion is an attempt to forget the unforgettable.

\section{The Burial of Phocion}

An additional significant aspect of the depiction of a journey in Burial of Phocion is its illustration of Johnson's overriding preoccupation with the kinesthetic experience of approach and 
arrival-what he called "the processional". He was especially fond of the landscape device known as the "hide and reveal," a physical dramatization of the play between known and unknown, mystery and discovery, suspense and surprise. The approach to the Glass House is one such example: ${ }^{20}$

The speed of ascent ... is crucial. Time to look around, to feel the change that a rise gives. The curiosity of what is on top, the question: What will I see from up there? (Johnson, 1979, p. 154).

The rendered narrative of Phocion's posthumous journey is continued in Landscape with the Ashes of Phocion, the pendant painting to Burial of Phocion (Fig. 5). ${ }^{21}$ Following Plutarch's account, in Ashes of Phocion, Phocion's widow surreptitiously gathers his remains after his cremation in Megara, a suburb of Athens before bringing them back to Athens.

Phocion's wife ... assisting at the [cremation in Megara], raised there an empty tomb, and performed the customary libations, and gathering up his bones in her lap, and bringing them home by night, dug a place for them by the fireside in her house, saying, 'Blessed hearth, to your custody I commit the remains of a good and brave man, and, I beseech you, protect and restore them to the sepulchre of his fathers, when the Athenians return to their right minds' (Plutarch, 1909, pp. 368-369).

We have looked within Burial of Phocion to understand the house that enframes it. In the painting, there is a path. Where does it lead? Let us follow Carrier's (1993) advice, and look without the painting.

Since what is within the frame seems to extend beyond the physical boundaries of the picture, it is natural to look outside the picture to understand what is within (p. 26).

If we "unframe" Burial of Phocion as situated, and extend Phocion's path beyond the frame of the painting, its trajectory points squarely toward the hearth of the Glass House-an 


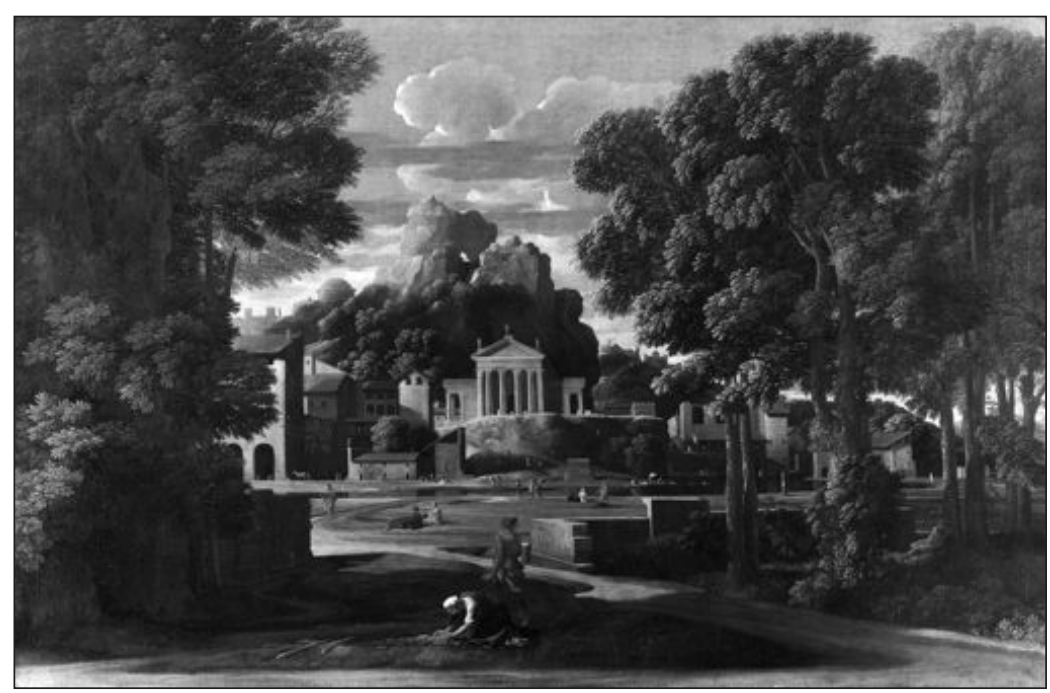

Figure 5. Landscape with the Ashes of Phocion, N. Poussin, 1648, private collection, Great Britain. Image (C) Scala/Art Resource, New York. Used with permission.

evocation of the temporary burial place where Phocion's remains were kept until his honor was restored (Fig. 6, top). The precise placement of the painting with respect to the hearth effects a perfect contiguity between the subject in the context of the painting and the subject in the context of the painting's setting, supporting the proposition that the subject of the painting is the subject of the house. Like Phocion's bones, this relationship, too, was interred.

This play on the relationship between reality and its symbolized depiction is in all likelihood a private wink toward a series of paintings by Magritte, La Condition Humaine, important works that would have been well known to Johnson. All are exercises in trompe-l'œil, in which a painted painting, mounted on an painted easel in front of a painted window, replicates the very part of the painted view it obstructs (Fig. 7, left). The Poussin in the Glass House achieves an analogous effect, only an actual painting mounted on an actual easel obstructs an actual view (Fig. 7, right). ${ }^{22}$ Of note, both the Magritte and the Poussin include a prominent tree in front of the horizon beyond-and, at the Glass House, a towering real oak mirrors the one in the Poussin. 

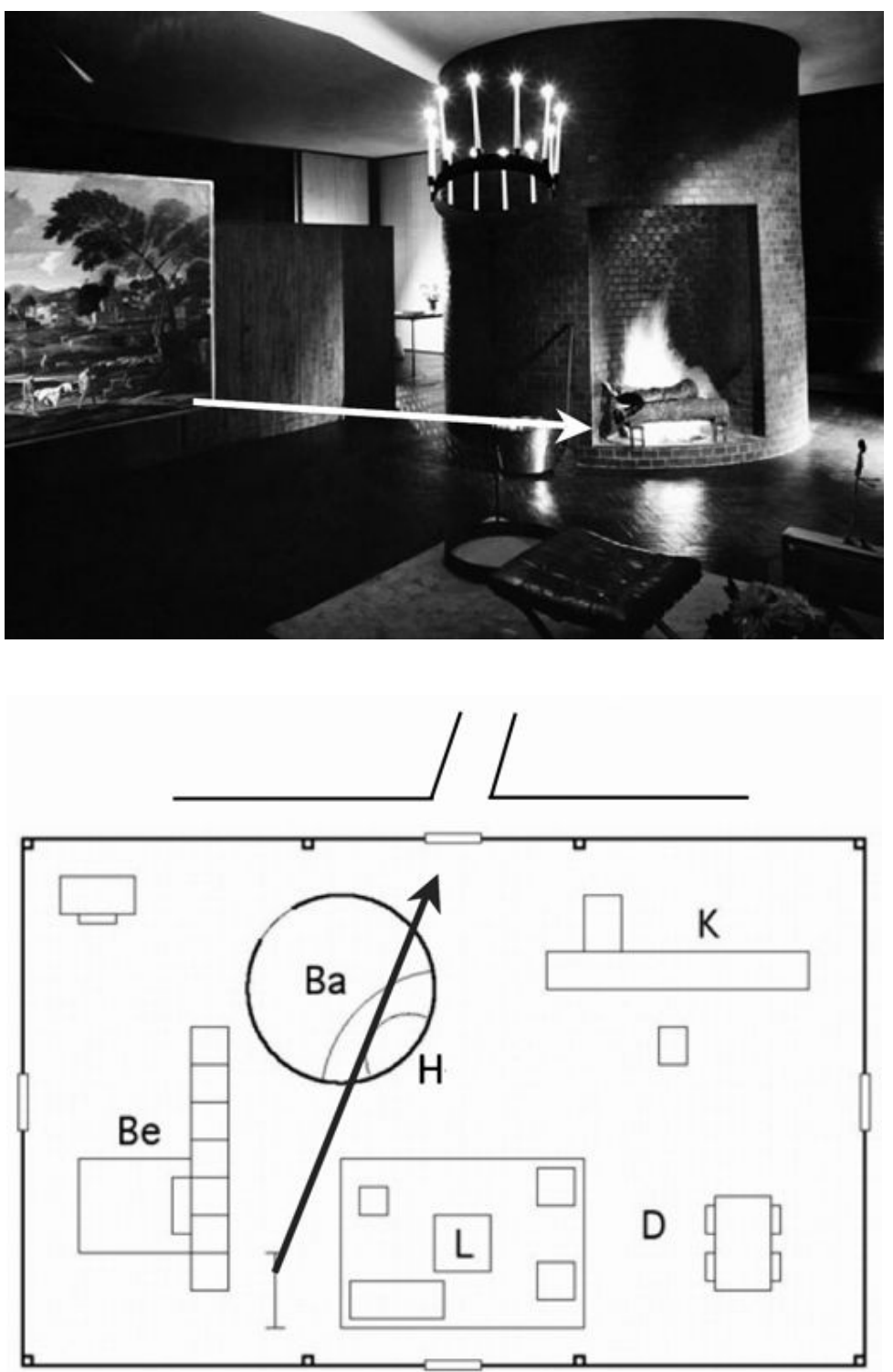

Figure 6. top: the New Canaan Burial of Phocion, installation view; when Phocion's path is extended (arrow), it leads directly to the hearth. Photographer unknown; however, the image must date from at or before the early 1950s, when the candelabra pictured was replaced by a different fixture. bottom: floor plan of the Glass

House. When its trajectory is extended further via the angle of the path from background to foreground, the path passes through the hearth $(\mathrm{H})$ and toward the direction of the door and the path beyond. Plan, courtesy of the Philip Johnson Glass House, National Trust for Historic Preservation. 

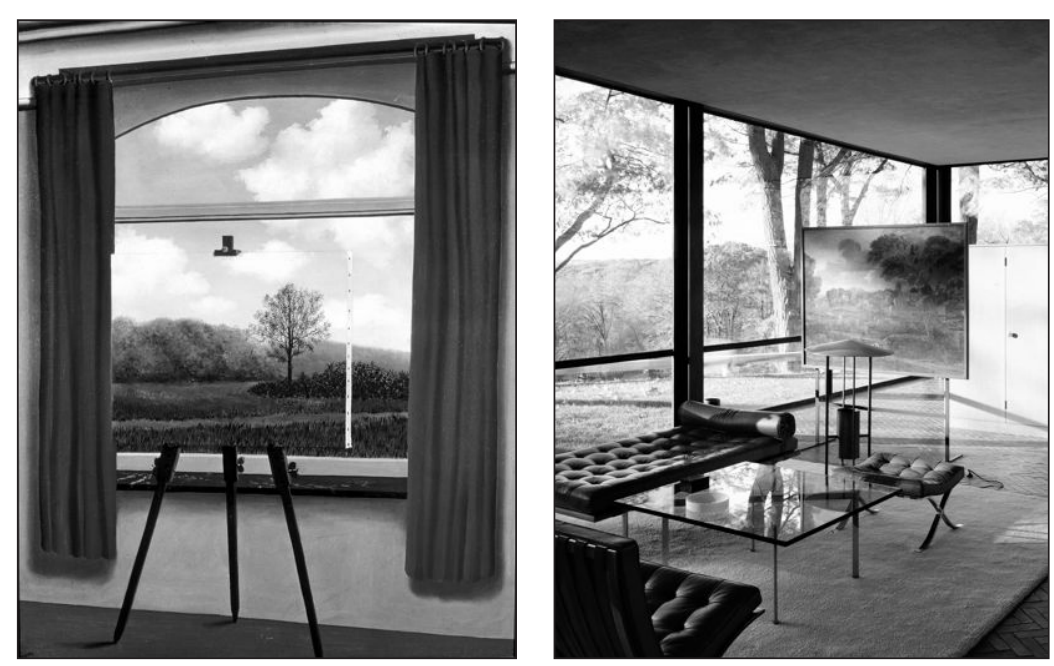

Figure 7. left: La Condition Humaine, René Magritte, 1933. Private collection. Image (C) Herscovici/Art Resource, New York. Used with permission. right: Burial of Phocion, in situ at the Glass House. Note the contiguity of inner and outer horizons; also note the painting's distinctly poorer state of conservation as compared to that in the older photograph, taken approximately fifty years earlier (Fig. 6, top). Photograph (c) Michael Moran. Used with permission.

La Condition Humaine offers a wry comment on the aesthetic illusion: the notion that art provides a "window" onto reality. In this image, Magritte observes that our perception of reality is as subjective and distorted as its artistic depiction-a difficult and oft disowned reality in and of itself-and implies that our "realities" are no more "real" than their representations. Like a dream-within-a-dream that disavows its embedded narrative, Magritte's conceit questions the boundaries between inner and outer realities, visualizing Edgar Allan Poe's famous lines:

Is all that we see or seem

But a dream within a dream?

What we seem to $b e$ is just as uncertain as what we seem to see. Like La Condition Humaine, the Poussin replaces the vista that it masks with a similar, but nevertheless altogether different one: the story of Phocion is a forgiving, flattering, narrative, around which Johnson could reframe or even exonerate his own. Is Johnson's narrative clarified or confounded by its juxtaposition with Phocion's? Perhaps both, adding paradox to parallel. 
As an adult, Johnson grew estranged from his parents, and only rarely returned to his home in Cleveland from his exile in Connecticut. He died alone, at the Glass House, at age ninety-eight.

In Poussin's second self-portrait, a gift to Chantelou, he stands in front of several canvases; on one is inscribed his name and place of birth, Les Andelys (Fig. 2). In his exquisitely subtle disquisition on this self-portrait, Carrier (1993) observes that "a shadow is cast across a text. Soon the shadow will move from its present position, where it cuts across Poussin's Christian and family names" (p. 9; see detail, Fig. 2). Splitting Nicola of Rome from la famille Poussin and its home in Les Andelys, this dividing line represents not only the distance between Poussin and his friend Chantelou, but also the distance between a man, his family, and France, and his mother country-leur patrie. The evanescent shadow signifies a lifetime as an expatriate, the passing of time, and the passing of life. If the shadows thrown by the trees in Johnson's Glass House chiaroscuro are its sundial, the New Canaan Poussin, inexorably ruined by the relentless sun, is its hourglass.

And if Burial of Phocion is the principal signifier of the Glass House, which frames, contains, and focuses it, Phocion is the avenged avatar of its architect. But Phocion's path did not end in Megara, nor does it end at the hearth of the Glass House. If we extend it further, and traverse the hearth, its extrapolated trajectory aligns exactly with the door and thence with the path leading to other Glass House buildings, including the sepulchral Painting Gallery (Fig. 6, bottom). Modeled after the Tomb of Atreus, the Painting Gallery, as magnificent a tomb as Phocion may have deserved, leads us to other encrypted representations of power, exile, and destruction.

But here facing the hearth stands the Nadelman; the smoothed, gentle features and mottled terracotta patina of its softly composed couple evoke the calm aura of prehistoric antiquity. And here, alongside of the hearth, is the Poussin; its shepherd and flock designate the nostalgic vision of lost pastoral splendor: Arcadia, which, "even when painted as if illusionistically present," "is of the past" (Carrier, 1993, 171). As Phocion's bitter processional leads to the waiting hearth, the oak tree leans toward it, as if to tenderly caress him; it simul- 
taneously embraces the distant landscape, linking Phocion's journey into the future with the past from whence he came. ${ }^{23}$ The tree shelters the path that leads to the hearth—the heart—of the Glass House; its canopy aligns with the realized Arcadian horizon. Thus joined are future and past, hearth and horizon. This, too, was intentional. Like Magritte, Johnson edited and pruned his trees to create the illusion of contiguity. Like Poussin, he had "neglected nothing."

\section{Notes}

1. Poe, 2000, pp. 450-452.

2. Hereafter referred to as "the Poussin," or Burial of Phocion (1648).

3. This may help explain Drexler's dismissal of the canvas, before the renaissance of popular and academic interest in Poussin.

4. See, for example, Krauss (1986) and Owens (1994). Given the criticism of Johnson's following "fashion" in his traveling from modernism to postmodernism in design, it is ironic that in determining the covert historicism in modernism, Johnson was postmodern before postmodernism.

5. From Johnson, 1979, p. 248 and Lewis \& O'Connor, 1994, pp. 159, 173, 173, respectively, italics added.

6. Biographical information in this essay is largely drawn from Blunt, 1967; Christiansen, 2008a; and Thuillier, 1995.

7. Franz Schulze (1994), Johnson's biographer, noted that he "spoke of Barr as he spoke of no one else, with a memorably guileless affection" (p. 47). Johnson's feelings are reflected in his habit of calling Barr "God," a name formerly reserved for Mies van der Rohe.

8. Nearing ninety at the time of this writing, and at the zenith of his fame, observe the persistence of Johnson's deference to his idealized colleagues.

9. Consistent with the traditional criticism of Poussin and Johnson as lacking in genius are the ubiquitous comments made about their achieving their calling relatively late in life, in direct opposition to the mythic narrative of the child prodigy who prefigures the divino artista, a dialectic skillfully demonstrated by Kris and Kurz in their consummately elegant essay, Legend, Myth, and Magic in the Image of the Artist: A Historical Experiment (1934).

10. Haskell (1995) further notes that such present-day criticisms reflect the lack of attunement with classical and mythological references that was usual in Poussin's time: "the extent of Poussin's reading impressed his contemporaries, but none of them seems to have implied that his imagery was difficult to understand" (p. 44).

11. Indeed, Johnson considered himself a "landscape architect"; he, along with Frank Lloyd Wright, is widely credited for bringing attention to the critical relationship between architecture and its setting.

12. For this reason, the New Canaan Burial of Phocion is technically "attributed" to Poussin and/or his school. Two other copies are known, one in the National Museum Cardiff, Wales, and one shown in Fig. 1, in the Hotel Matignon.

13. In fact, The National Trust has prioritized Johnson's placement of the Poussin's position in the Glass House over its conservation.

14. Johnson learned Greek from his mother as a child and as an undergraduate at Harvard specialized in classics, concentrating in ancient Greek.

15. The Phocion cycle comprises two paintings, Burial of Phocion and the better-known Landscape with the Ashes of Phocion (fig. 5), both completed c. 1648. 
16. A former Philip Johnson Chief Curator of Architecture and Design at MoMA.

17. Press release, National Trust for Historic Preservation, January 15, 2008.

18. Johnson also installed huge Carrera marble renditions of Two Circus Women and its companion sculpture in the lobby of the New York State Theatre Johnson designed, home of the New York City Ballet, which Kirstein founded (Fig. 4, right). Kirstein was instrumental in helping to secure this commission for Johnson.

19. The Nadelman sculpture also recalls the multiply determined themes of feminine identifications and the wish for fusion with an idealized maternal object (Tutter, in press).

20. Interestingly, Freud deliberately employs the hide and reveal in The Interpretation of Dreams, itself a literary example of a journey (Shengold, 1966); as Freud deliberately employs the hide and reveal; as Freud (1899, August 6) explained to Wilhelm Fliess, "The whole thing is planned on the model of an imaginary walk. At the beginning, the dark forest of authors (who do not see the trees), hopelessly lost on the wrong tracks. Then a concealed pass through which I lead the reader... and then suddenly the high ground and the view and the question: which way do you wish to go now?" (p. 365).

21. "Pendant" paintings were meant to be hung one above the other.

22. The author is indebted to Dr. Hilary Beattie for pointing out the important relevance of the Magritte paintings to the New Canaan Poussin.

23. Phocion was executed on one of the festivals of Jupiter. The oak tree, prominent in the foreground of the painting, is a symbol of Jupiter, linking Phocion to the celebrations honoring him, visible in the far background of the painting, and perhaps suggesting that Phocion himself deserved such recognition.

\section{References}

Bachelard, G. (1958). The poetics of space. Boston: Beacon Press, 1994.

Balter, L. (2005). Nested ideation and the problem of reality: Dreams and works of art in dreams. Psychoanalytic Quarterly, 74, 661-701.

Balter, L. (2006). Nested ideation and the problem of reality: Dreams and works of art in works of art. Psychoanalytic Quarterly, 75, 405-445.

Bayrle, T., \& Zybach, A. (2003). Layout. Philip Johnson im Gespräch mit Rem Koolhas und Hans Ulrich Obrist. Köln, Germany: Verlag der Buchhandlung Walther König.

Blunt, A. (1967). Poussin. Washington, DC: Trustees of the National Gallery of Art.

Carrier, D. (1993). Poussin's paintings: A study in art-historical methodology. University Park, Penn.: Pennsylvania State University Press.

Cavina, A. O. (2008). Poussin and the Roman Campagna: In search of the absolute. In P. Rosenberg \& K. Christiansen (Eds.), Poussin and nature: Arcadian visions (pp. 39-50). New York: Metropolitan Museum of Art.

Christiansen, K. (2008a). The critical fortunes of Poussin's landscapes. In P. Rosenberg \& K. Christiansen (Eds.), Poussin and nature: Arcadian visions (pp. 9-38). New York: Metropolitan Museum of Art.

Christiansen, K. (2008b). A brief biography of Nicholas Poussin. In P. Rosenberg \& K. Christiansen (Eds.), Poussin and nature: Arcadian visions (pp. 119-126). New York: Metropolitan Museum of Art.

Démoris, R. (2008). From The Storm to The Flood. In P. Rosenberg \& K. Christiansen (Eds.), Poussin and nature: Arcadian visions (pp. 91-101). New York: Metropolitan Museum of Art.

Denio, E. H. (1899). Nicolas Poussin: His life and work. New York: Charles Scribner's Sons.

Drexler, A. (1949). Architecture opaque and transparent. In D. Whitney \& J. Kipnis (Eds.), Philip Johnson: The Glass House (pp. 3-8). New York: Random House, 1993.

Dunn, D. H., \& Maclear, C. (2008). The Glass House. New York: Assouline and The National Trust for Historic Preservation.

Eisenman, P. 1979. Introduction. In P. Johnson, Writings (pp. 10-26). New York: Oxford University Press. 
Franken, M. (2005). 'Pour mon honneur et pour vostre contentment': Nicolas Poussin, Paul Fréart de Chantelou and the making and collecting of copies. In M. van den Doel (Ed.), The learned eye: Regarding art, theory, and the artist's reputation (pp. 181-189). Amsterdam: Amsterdam University Press.

Freud, S. (1899, August 6). Letter to Wilhelm Fliess. In J. M. Masson (Ed.), The complete letters of Sigmund Freud to Wilhelm Fliess 1887-1904 (p. 365). Cambridge, MA: Harvard University Press, Belknap Press, 1985.

Freud, S. (1900). The interpretation of dreams. Standard Edition (Vols. 4-5, pp. ix-627). London: Hogarth Press.

Grinstein, A. (1956). The dramatic device: a play within a play. Journal of the American Psychoanalytic Association, 4, 49-52.

Haskell, B. (2003). Elie Nadelman: Sculptor of modern life. New York: Whitney Museum of American Art.

Haskell, F. (1995, March 23). Poussin's season. New York Review of Books, 42 (5), 43-50.

Hitchcock, H.-R., \& Johnson, P. (1932). The international style. New York: W. W. Norton, 1995. (Originally issued in 1932 under the title The International Style: Architecture since 1922, reissued with new introductions in 1966 and 1995.)

Hitchcock, H.-R. (1966). Introduction. In P. Johnson, Philip Johnson: Architecture 1949-1965 (pp. 8-18). New York: Holt, Rinehart and Winston.

Huxtable, A. L. (1964, May 24). He adds elegance to modern architecture. New York Times Magazine, 18-20.

Johnson, P. (1950). Residence in New Canaan. Architectural Review 108, 152-159.

Johnson, P. (1979). Writings. New York: Oxford University Press.

Kipnis, J. (1993). Throwing stones-the incidental effects of a Glass House. In D. Whitney \& J. Kipnis (Eds.), Philip Johnson: The Glass House (pp. x-xxxii). New York: Random House.

Kipnis, J. (1996). Philip Johnson: Recent work. London: Academy Editions.

Krauss, R. (1986). The originality of the avant-garde and other modernist myths. Cambridge, MA: MIT Press.

Kris, E., \& Kurz, O. (1934). Legend, myth, and magic in the image of the artist: A historical experiment. (A. Laing and L. M. Newman, Trans.). New Haven: Yale University Press, 1979.

Kris, E. (1956). The personal myth-a problem in psychoanalytic technique. Journal of the American Psychoanalytic Association, 4, 653-681.

Lamberton, R. (2003). Plutarch's Phocion: melodrama of mob and elite in occupied Athens. In Palagia, O. \& Tracy, S. V. (Eds.) The Macedonians in Athens, 322-229 $B C$. (pp. 8-13). Oxford: Oxbow.

Lavin, S. (2004). Form follows libido: Architecture and Richard Neutra in a psychoanalytic culture. Cambridge, MA: MIT Press.

Lewis, H. (2002). No rules, just art. In S. Fox, P. Johnson, H. Lewis, \& R. Payne, The architecture of Philip Johnson (pp. 3-11). Boston: Bulfinch Press.

Lewis, H. \& O'Connor, J. (1994). Philip Johnson: The architect in his own words. New York: Rizzoli International Publishers.

Ockman, J. (2009). The figurehead: On monumentality and nihilism in Philip Johnson's life and work. In E. Petit (Ed.), Philip Johnson: The constancy of change (pp. 82-109). New Haven: Yale University Press.

Olson, T. (2002). Poussin and France: Painting, humanism, and the politics of style. New Haven: Yale University Press.

Owens, C. (1978). Philip Johnson: History, genealogy, historian. In D. Whitney \& J. Kipnis (Eds.), Philip Johnson: The Glass House (pp. 81-90). New York: Random House, 1993.

Owens, C. (1994). Beyond recognition: Representation, power, and culture. Berkeley and Los Angeles: University of California Press.

Pace, C. (2008). Peace and tranquility of mind: The theme of retreat and Poussin's landscapes. In P. Rosenberg \& K. Christiansen (Eds.), Poussin and nature: Arcadian visions (pp. 73-90). New York: Metropolitan Museum of Art.

Plutarch (1909). Lives. New York: Little, Brown. 
Poe, E. A. (2000). Complete poems. T. O. Mabbott (Ed.). Champaign, Ill.: University of Illinois Press.

Poussin, N. (1824). Collection de lettres. A. C. Q. de Quincy (Ed.). Paris: Firmin Didot. Original book from the Library of Oxford University [Google Books version, June 15, 2006.] Retrieved August 31, 2011 from http://books.google.co.uk/ books?id=ijwBAAAAQAAJ.

Riley, T \& Sacks, J. (2009). Philip Johnson: Act one, scene one-the Museum of Modern Art? In E. Petit (Ed.), Philip Johnson: The constancy of change (pp. 60-67). New Haven: Yale University Press.

Said, E. (1994). Representations of the intellectual: The 1993 Reith Lectures. New York: Vintage.

Sauerländer, W. (2008). "Nature through the glass of time": A reflection on the meaning of Poussin's landscapes. In P. Rosenberg \& K. Christiansen (Eds.), Poussin and nature: Arcadian visions (pp. 103-118). New York: Metropolitan Museum of Art.

Shengold, L. (1966). The metaphor of the journey in "The Interpretation of Dreams." American Imago, 23 (3), 316-331.

Shirer, W. (1941). Berlin diary: The journal of a foreign correspondent 1934-1941. New York: Alfred A. Knopf.

Schulz, F. (1994). Philip Johnson: life and work. Chicago: University of Chicago Press.

Scully, V. (1986). Philip Johnson: The Glass House revisited. In D. Whitney \& J. Kipnis (Eds.), Philip Johnson: The Glass House (pp. 153-157). New York: Random House, 1993.

Scully, V. (2003). Modern architecture and other essays. Princeton: Princeton University Press.

Scully, V. (2009). Art and irony. In E. Petit (Ed.), Philip Johnson: The constancy of change (pp. 18-37). New Haven: Yale University Press.

Sorkin, M. (1988). "Where was Philip?" In Exquisite corpse: Writing on buildings (pp. 307-311). New York: Verso, 1991.

Steefel, L. D. (1991). A narrative reading of Poussin's Phocion paintings. Art Review [Konsthistorisk tidskrift], 60, 9-16.

Stern, R. A. M. (2008). The Philip Johnson Tapes. New York: Monacelli Press.

Thuillier, J. (1995). Poussin before Rome, 1594-1624. (C. Allen, Trans.). London: Richard L. Feigen \& Co.

Tritle, L. A. (1988). Phocion the Good. New York: Croon Helm.

Tutter, A. (2011). Design as dream and self-representation: Philip Johnson and the Glass House of Atreus. Journal of the American Psychoanalytic Association, 59, 509-548.

Tutter, A. (in press). A violent atomization: attachment vs. autonomy at the Philip Johnson Glass House. In Benedikt, M. L., Danze, E. A., \& Sonnenberg, S. M. (Eds.), Center 17: Space and psyche. Austin, Texas: University of Texas, Center for American Architecture and Design.

Wright, C. (2007). Poussin: Paintings: A Catalogue Raisonné. London: Chaucer Press. 